RESEARCH ARTICLE

\title{
LAW ENFORCEMENT OF MOTORIZED VEHICLES WITH MUFFLER RACING BY MAGELANG CITY POLICE
}

\author{
Damas Reza Kurniadi $1_{\varpi}$ \\ ${ }^{1}$ Legai Aid Center of UIN Walisongo, Branch Kebumen, Indonesia \\ $\square$ drezakurniadi@yahoo.co.id
}

\section{HOW TO CITE}

Kurniadi, D.R. (2020). Law Enforcement of Motorized Vehicles with Muffler Racing by Magelang City Police. Journal of Law and Legal Reform, 1(1), 77-92. DOI: https://doi.org/10.15294/jllrorm.vlil.35415

\begin{abstract}
Muffler is a facility to dispose of exhaust gases that result from combustion in a motorcycle engine when the engine is started. Motorcycle riders often replace the standard muffler with a harder or racing muffler. Basically, muffler modification is considered a violation of the law. Based on the description above, the formulation of the problem that will be discussed in this research is how to implement regulations regarding the use of motor racing exhausts on public roads?, And how the actions taken by the Magelang city police resort in dealing with the use of mufflers racing? The results of research and discussion indicate that law enforcement in the case of the use of motorcycle racing mufflers is included in law enforcement in the field of traffic. Law enforcement in the field of traffic can be grouped into preventive and repressive law enforcement. The conclusion drawn from this study is that the implementation of regulations regarding the use of motorbikes with racing mufflers on public roads has been carried out in accordance with the law. The action taken by Police is to carry out traffic and seizure actions taking into account the effects of pollution on the use of mufflers racing which not only damage human health but also damage the environment.
\end{abstract}

Keywords: Law Enforcement; Racing Muffler, Magelang City Police Department 


\section{TABLE OF CONTENTS}

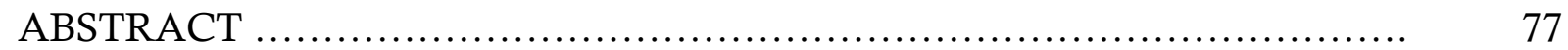

TABLE OF CONTENTS ................................................... 78

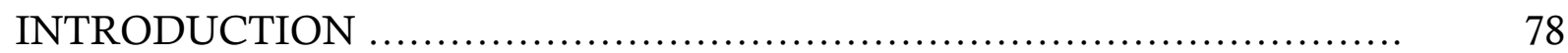

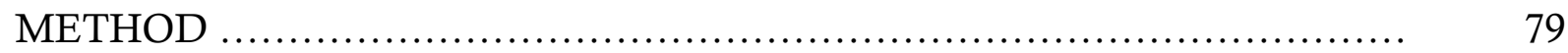

MUFFLER RACING AND LAW ENFORCEMENT ........................ 80

I. IMPLEMENTATION OF REGULATIONS AGAINST THE USE OF MOTORIZED VEHICLES WITH "MUFFLER RACING" IN THE MAGELANG MUNICIPAL POLICE .................................... 80

A. Reality of Violation ................................................. 80

B. Law Enforcement ............................................... 81

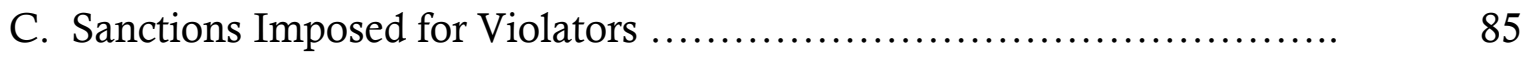

II. ACTIONS ARE TAKEN BY THE MAGELANG MUNICIPAL POLICE IN HANDLING THE USE OF "MUFFLER RACING" ON PUBLIC ROADS ................................................................................... 85

A. Reasons for Legal Action ............................................. 87

B. Effects of Pollution Caused by Racing Exhaust ........................ 88

CONCLUSION ........................................................... 88

REFERENCES ......................................................... 89

\section{INTRODUCTION}

Modernization has a very real impact on people's lives, changing times are very fast in various fields causing various problems that are very complex (Mathijsen, 2017). Besides modernization, problems also arise from globalization. Differences in views and thoughts from globalization together with modern lifestyles lead to behaviors or activities that are considered to be deviant and considered detrimental to society (Guimarães \& da Silva, 2019).

One of the public behavior that is rife in the modern world today is the behavior of people traveling using private transportation. In this day and age transportation becomes very important in living everyday life. To travel far now the community can easily and quickly get to the place they want to go. This is all thanks to the results of human thought itself which is able to create and develop transportation tools that are very helpful in our daily lives. One of the most widely used means of transportation for our society is a motorcycle.

Industrial production of motorcycles made in Indonesia originals and those made outside Indonesia that are assembled in Indonesia is increasingly diverse, so people are interested in buying motorbikes. From this, it can be seen that there are so many shapes and models as well as various kinds of desires of different people to buy the motorbike they want. The community also needs to choose what kind of 
motorbike they want to ride in order to provide benefits and prestige that they feel are more confident when they ride the motorcycle. For people who want to own a motorcycle, not all want to use standard factory bikes so that the motorcycle is modified in such a way and changes any parts or accessories that are on the motorcycle so that it does not care about comfort and safety, safety which should be more important to pay attention to in traffic.

Motorcycle modification that is often done by the public is the replacement of the muffler. Muffler is a means of removing exhaust gases arising from combustion in a motorcycle engine when the engine is started (Adnan \& Gazder, 2019). People often replace the muffler using mufflers that have a louder sound or better known as "racing exhaust". The motorcycle which is replaced by the muffler is believed to be able to increase power even the motorcycle will look more ferocious because of the noise caused when driving on public roads.

On the other hand, we buy motorbikes, we definitely use them on the highway, and the highway is the only route for motorized motorists who have traffic rules. From the replacement of the muffler the loud noise which was raised by the motorcycle on public roads, the other community became uncomfortable because it was considered noisy. Even though people in traffic on public roads have the right to live comfortably without noise(van Dijk et al., 2019). From this, there arose a rule that regulates every motorist to drive properly and correctly for the sake of safety with fellow road users. In addition to mutual safety, motorcycle drivers also need to pay attention to the comfort and safety of the vehicle for daily activities. However, in its implementation, the enforcement of the use of "racing exhaust" is still considered controversial.

\section{METHOD}

This study uses legal research with a legal qualitative research approach (Redelmeier, Tibshirani, \& Evans, 2003). The definition of legal qualitative research is research that is actually a research procedure that produces descriptive data, i.e. what is stated by the respondent in writing or verbally, and real behavior (Sheng et al., 2018). The thing that is studied and studied is a whole object of research, as long as it concerns humans. Thus, by using a qualitative approach, a researcher primarily aims to understand or comprehend the symptoms being examined (Rosenfeld, 2019). This type of research is sociological-juridical. The focus of research on law enforcement of motor vehicles with exhaust mufflers in the Magelang City Police jurisdiction. Data sources use primary and secondary data sources with data collection techniques in the form of literature studies, interviews, observations, and documentation. Data validity with data triangulation techniques and data analysis using descriptive analysis. 


\section{MUFFLER RACING AND LAW ENFORCEMENT}

\section{IMPLEMENTATION OF REGULATIONS AGAINST THE USE OF MOTORIZED VEHICLES WITH MUFFLER RACING IN THE MAGELANG MUNICIPAL POLICE}

A. Reality of Violation

Based on research conducted at the Magelang City Police Traffic Unit, it is found that the violation of the use of motorbike "exhaust mufflers" in the Magelang City Police area, the authors have observed during "the Zebra Operation" Magelang city Police Station in October 2017. The results of observations obtained the following data.

Table 1 Data Muffler Racing Drivers during Zebra Operation

\begin{tabular}{clll}
\hline No & Driver, Type of Motorcycle & Sanction & Note \\
\hline 1 & 'Black Ninja type' Driver & $\begin{array}{l}\text { Ticket } \\
\text { (tilang) }\end{array}$ & Investigated by IPDA \\
& & Released & Investigated by BRIGPOL \\
2 & 'Green Ninja type' Driver & Tilang & Investigated by eh AIPDA \\
3 & KLX type Driver & Released & Investigated by BRIGPOL \\
4 & Blue GSX type Driver & Released & Investigated by BRIPDA \\
5 & Byson type Driver & Tilang & Investigated by BRIPDA \\
6 & Mio type Driver & Tilang & Investigated by BRIPDA \\
7 & Supra type Driver & Tilang & Investigated by BRIPKA \\
8 & KLX type Driver (student) & Tilang & Investigated by IPDA \\
9 & Pengendara sepeda motor & & \\
& KLX (umum) & Investigated by BRIPKA \\
10 & $\begin{array}{l}\text { Pengendara sepeda motor v- } \\
\text { ixion }\end{array}$ & Tilang & \\
11 & Pengendara sepeda motor & Tilang & Investigated by BRIPDA \\
& KLX & & \\
\hline
\end{tabular}

Source: Zebra Operations Observation Data, Magelang City Police Department

In this table, the author can conclude in the case of traffic violations, especially in handling the use of "racing exhaust" there are different measures. Where there are drivers who act with a crossing and some are released (released from the ticket or tilang). This can occur because there is a separate understanding from each Police member regarding the handling of special cases. In the implementation of traffic operations, there are several different levels of police officers' positions, therefore, it can be concluded that there are also different actions in handling a case because of different levels of knowledge about a matter.

Law No. 22 of 2009 emphasized that traffic is the movement of vehicles and people in the road traffic space, while transportation is the movement of people or 
goods from one place to another using vehicle in the road traffic room (Alghuson, Abdelghany, \& Hassan, 2019). Whereas what is meant by Road Traffic Space is Infrastructure intended for moving vehicles, people, and/or goods in the form of Roads and supporting facilities (Ali, Yaseen, \& Khan, 2019). The government has the authority to realize traffic and road transportation that is safe, fast, smooth, orderly, and orderly, comfortable and efficient through traffic management and traffic engineering. The procedures for traffic on the road are governed by laws and regulations concerning traffic safety and road transportation, traffic safety and road transportation, and traffic order and road transportation (Aney \& Ho, 2019).

\section{B. Law Enforcement}

In a study conducted by the writer at the Magelang city Police Traffic Traffic Unit, the author obtained the results where the writer conducted an interview with Mr. Ronny on September 13, 2017, "The law enforcement activity program is not oriented towards finding faults from road users but rather oriented to protection, guidance, and user services. The road that violates itself, other road users, and the importance of disclosing criminal cases "

Law enforcement against the use of motor "exhaust exhaust" itself included in law enforcement in the field of traffic. Law enforcement in the field of traffic can be grouped into several sections, namely (Bracco, 2018):

a. Preventive law enforcement (non-penal) includes traffic management activities, traffic control, traffic control, and traffic patrol, which in the implementation of these activities constitutes a traffic safety system which can be separated from other sub-systems.

b. Repressive law enforcement includes the act of violation and investigation of traffic accidents.

Enforcement of traffic laws in the educational field, namely carrying out acts of traffic violations sympathetically by giving warnings or warnings against traffic violators, whereas legally it can be interpreted as legal violations of traffic violations which include actions using tickets (Takeuchi, 2019).

Muffler is a channel to dispose of the remaining combustion results in the internal combustion engine. The exhaust system consists of several components, consisting of at least one drain pipe (Castillo-Manzano, Castro-Nuño, LópezValpuesta, \& Pedregal, 2019). While Racing means speeding (racing). So "exhaust racing" is the disposal of the remaining combustion results on the motorcycle racing engine. The use of "racing exhaust" itself on a motorcycle is believed to improve the performance of the vehicle ridden by its users. In addition to the higher performance of the use of "racing exhaust" is felt to make the vehicle rider fierce because when the vehicle is driven on the road the sound of the muffler is very loud not smooth like a motorcycle in general.

As explained by the informant that law enforcement regarding the handling of motorbike "exhaust mufflers" in the jurisdiction of the Magelang Police City refers to Law Number 22 of 2009 concerning Traffic and Road Transportation Article 285 paragraph (1). Based on the police function mandated in Article 2 of the Law of the 
Republic of Indonesia Number 2 of 2002 it is stated that the function of the police is one of the functions of the state government in the field of maintaining security and public order, law enforcement, protection, protection and service to the community. So with this function, placing the police as the state apparatus in terms of maintaining security and order, law enforcement, protection, protection, and service to the community always intersects with the interests of the wider community.

As Prof. Dr. Walter C. Reckless commented that "The good and bad situation of security and public order (Kamtibmas) of a country is affected by at least five things, namely: how the system and organization of the police are, how the legal system, how the judiciary, how the bureaucratic system in building Kamtibmas and law enforcement, and how community participation" (Crisanti, Earheart, Rosenbaum, Tinney, \& Duhigg, 2019).

The police institution is one institution that is expected by the public at large to play a role in every line of life, which role is based on rules (norms) to be used as a foothold of role models in the development of the mentality of the nation and continue to uphold the values human rights value (Watling, 2018).

Violation of exhaust racing which is often a problem in traffic carried out by motorcycle clubs is usually deliberately carried out for reasons that are not known or indeed do not know the rules that exist in Law No. 22 of 2009. Most of the motorcycle clubs do not heed their own safety and tend not to care about the safety of others, this is reflected in the violations committed by the motorcycle club. For these violations, the police carried out law enforcement beginning with the inspection of the completeness of the motor vehicle certificate. As the interview conducted by the author with Mr. Ronny, Baur ticketed the Magelang city Traffic Satlantas.

The implementation of other law enforcement is emphasized through Minister of Environment Regulation No. 7 of 2009 concerning New Type Vehicle Noise Thresholds. In Appendix II of the Minister of Environment Regulation No. 7 of 2009 which has been explained on Table 2 as follow:

Table 2 Noise Threshold

\begin{tabular}{|c|c|c|c|}
\hline \multirow{2}{*}{\multicolumn{2}{|c|}{ Category }} & \multirow{2}{*}{\multicolumn{2}{|c|}{$\begin{array}{c}\text { L Max dB } \\
\text { Year of Application }\end{array}$}} \\
\hline & & & \\
\hline & & (i) & (ii) \\
\hline \multirow[t]{3}{*}{ Motorcycle } & L up to $80 \mathrm{cc}$ & 85 & 77 \\
\hline & $80<\mathrm{L}$ up to $170 \mathrm{cc}$ & 90 & 80 \\
\hline & $\mathrm{L}>175 \mathrm{cc}$ & 90 & 83 \\
\hline
\end{tabular}

Information: L: Vehicle

Source: Appendix II of the Minister of Environment Regulation

In the regulation it is clear and detailed but in its implementation in the enforcement of motorbike "exhaust mufflers" by the Magelang City Resort Police, especially the Traffic Unit of Magelang City Police, if the ministerial regulation is used as a legal basis for law enforcement against the use of "exhaust mufflers" there are still considered obstacles. 
The obstacle when the police take action against violators when referring to Ministerial Regulation number 7 of 2009 is the limited means to measure noise from the sound produced by the exhaust.

\begin{abstract}
"Noise meters have so far only been owned by the transportation department. Therefore, in the implementation of the ticket regarding "racing exhaust", the Magelang City Police Department used the basis of Law number 22 of 2009 Article 285 paragraph (1), so that later there would be no questions about noise measuring devices". (Personal Interview with Bribka Ronny on September 13, 2017)
\end{abstract}

If observed in the implementing regulations there are definite thresholds regarding noise levels, if seen from that the police need to measure using noise gauges. The noise measurement tool itself is only owned by the Transportation Department, in addition to that the technical testing of the exhaust noise level is only the Transportation Department which is in-depth, then for the testing method also requires an adequate place for testing the noise level of the exhaust itself.

If using the basis of Law number 22 of 2009 Article 285 paragraph (1) actually there are also other obstacles, namely regarding technical requirements and roadworthiness. Technical requirements and road-worthiness that are well understood and know the standardization are the Department of Transportation.

In the case of the "exhaust racing" regulation which in this case is included in modifying the vehicle when questioning the technical requirements and roadworthiness, there should be a license from the relevant service which is stated in Article 50 of Law number 22 of 2009 and Government Regulation Number 55 of 2012 Article 14.

Although there are many obstacles in the field, the Magelang City Resort Police still adhere to the Traffic Law:

\begin{abstract}
"The police continue to use the existing Article Article 285 of Law No. 22 regarding road traffic and transportation on the grounds that circulation and use of" racing exhausts "on the streets can be minimized. Although the public defends that the use of" racing exhausts "does not neglect the rules if left unchecked and not being acted out fear is considered legal. "If a motorcycle already has a license that has been tested for roadworthiness, then the owner is changed, even though there is only one change, then it can be included Article regarding the standardization of motor vehicles, namely Article 285 of Law No. 22 of 2009" (Personal Interview with Mr. Ronny on September 13, 2017)
\end{abstract}

This is consistent with the theory of justice which sets criteria in carrying out everyday law, namely the police must have a general standard to recover the consequences of actions committed by traffic violators. The standard is applied without discriminating against people (Ali, 2010: 51). The police, in this case, must 
have a definite legal basis, where although in the inspection of the motorized vehicle the officers will differ but if the police have a definite legal basis. Stubborn people who are looking for loopholes in the Traffic and Road Transportation Law will certainly be minimized and the police can still maintain their opinions on the mistakes made by motorcycle riders examined by these officers.

In order to anticipate the existence of defense from the community because of the action of the use of "exhaust racing" Magelang City District Police held a joint operation. The involvement of other agencies is carried out so that in the implementation of traffic operations activities can create definite law enforcement. Because in each of these agencies have their own expertise to support and assist law enforcement in the field of traffic(Dur \& Vollaard, 2019). In the case of law enforcement, the use of "exhaust mufflers" considered to be able to help the technical test for law enforcement conducted by the Police is the Transportation Agency. The Transportation Agency is considered capable and understands the matter of vehicle maintenance and feasibility testing because the Transportation Agency better understands the physical condition of motorized vehicles. Whereas the police can only crackdown on violators.

\begin{abstract}
"When a vehicle is issued a permit from the State, the vehicle has a reference from DISHUB. The Transportation Agency has an ATPM where the vehicle whose license is already listed and registered with the Transportation Agency"

"Every vehicle that will be marketed in Indonesia with a minimum number of 10-plus must be tested in type first, which later will have a certificate of type test registration".
\end{abstract}

From the statement and written interview with the source person, Mr. Soleh Achirudin, the Vehicle Testing Manager of the Magelang City Transportation Department, the author provides an analysis related to the explanation of the results of the interview that the traffic problem is not an easy problem to solve. That is because there are many factors that influence therein. The creation of traffic order cannot be separated from human factors, although the regulations have been explained in detail if humans do not have a law-abiding nature, then these regulations will only become rules. Therefore it is necessary to grow a sense of public awareness in obeying traffic laws (Dzhuruk \& Zedgenizov, 2018). Effective socialization and enforcement efforts have also been carried out by the Magelang City Police Precinct to make the traffic law success in order to foster a sense of public awareness in traffic.

Law No. 22 of 2009 concerning road traffic and transportation is also expected to help realize legal certainty for parties involved both law enforcement officials, motorists, and pedestrians. There are three components of the occurrence of traffic, namely humans as vehicle and road users who interact with each other in the movement of vehicles that meet the eligibility requirements and are driven by the driver following the traffic rules established based on laws and regulations relating to 
traffic and road transportation through roads that meet the geometry requirements (Moore, 2019).

\section{Sanctions Imposed for Violators}

Sanctions imposed on violators are basically different, there are violators who are penalized by officers, there are also those who are reprimanded by officers and some are left alone by officers. This happens because there are different perspectives from the police itself because there are different levels from the position of the police officers who inspect motorcyclists (Wiens, Lenk, Fabian, \& Erickson, 2018; Arifin, 2019; Juliana \& Arifin, 2019).

This is very contrary to what was conveyed by sources about law enforcement using "exhaust racing". Where in the statement of the informant "the police continue to use the existing Article Article 285 of Law No. 22 regarding traffic and road transportation with the reason that circulation and use of" racing exhaust "on the road can be minimized. Ignoring the rules if left unchecked and not feared is considered legal. Unlike the case in the field when there is omission to the driver of a vehicle that uses "exhaust racing".

In handling traffic violations, the aforementioned Police Act No. 2 of 2002 does not violate rules because in their duties in Article 18 paragraph (1) which reads: "in the public interest of the Republic of Indonesia National Police officials in carrying out their duties and authorities, they can act according to their assessment alone."

The police institution is one institution that is expected by the public at large to play a role in every line of life, which role is based on rules (norms) to be used as a foothold of role models in the development of the mentality of the nation and continue to uphold the values human rights value (Factor, 2018; Muhtada \& Arifin, 2019).

From this the authors can conclude that the application of sanctions from handling the use of motor "exhaust racing" is different, it depends on the police officers who acted on it. Rank or Position and knowledge of the meaning of the governing law also influence what actions are taken when dealing with traffic violations because in their duties the police can carry out their duties and authority according to their own judgment (Article 18 of the Police Act No. 2 of 2002).

\section{ACTIONS ARE TAKEN BY THE MAGELANG MUNICIPAL POLICE IN HANDLING THE USE OF MUFFLER RACING ON PUBLIC ROADS}

Provisions in Law Number 22 of 2009 concerning Road Traffic and Transportation are basically to guarantee human safety in relation to road users. The risk is too great if Law Number 22 of 2009 concerning Traffic and Road Transportation is not very popular, both in urban communities and in rural communities, especially the younger generation, starting from basic education to university education. So that efforts in creating traffic order can be carried out and traffic smoothness is more guaranteed (Yan, Yan, Ren, Tian, \& Shi, 2018). 
Based on the results of the author's research in the Magelang City Police Traffic Unit. In the case of Traffic Violations concerning "exhaust mufflers" in Magelang City, the Magelang City Police Department took Preventive and Repressive measures to deal with this problem including

\title{
1) Preventive Step
}

Preventive measures taken by the Magelang City Police Department in anticipating or preventing the rise of the use of motor racing "exhaust racing" is the Socialization of Law No.22 of 2009, Providing Legal Counseling, Providing training (Friehe, Pham, \& Miceli, 2018). Based on the results of an interview with Mr. AIPTU Wahyudi Kaurmintu Traffic Police Unit (Satlantas) Magelang City Police Resort on September 13, 2017, who said that:

\footnotetext{
"The police are socializing because they consider the method to be quite effective and still carry out a public address that regulations are needed to make people aware of their own safety when driving on the highway."
}

He also said:

\begin{abstract}
"30 days after Law Number 22 of 2009 concerning Road Traffic and Transportation was passed it had to be enforced (whether the community knew it or not) but from the Magelang City Police Traffic Unit continued to provide authorization to motorists for 1 month, in the action also gave advance warning. "
\end{abstract}

What has been done by the Magelang City Police Station is in line with the theory of integrative law where law enforcement is not done through enforcement but with non-penalism through the inculcation of values that develop in society to make and enforce the law (Lee, Park, \& Lee, 2018). In the implementation of law enforcement in the field of traffic before carrying out an action must first instill the values that develop in the community so that later the community can realize the importance of the rule of law, especially the rule of traffic law so that later the goal of traffic activity and road transportation will be in accordance with listed in Law No.22 of 2009 concerning Road Traffic and Transportation.

\section{2) Repressive}

The repressive step taken by the Magelang City Police Department in suppressing the rise of the use of motorbike "exhaust racing" she Magelang City Police will incessantly always control or operate motorized vehicles. This operation is carried out on long holidays or even normal days such as the Rhombus Operation, Temple Operation, Candle Operation, Zebra Operation, Sympathetic Operation. This operation is carried out in order to reduce traffic violations, reduce the number of accidents, create security, safety, order, and smooth traffic and road transportation. 
In the operation of the vehicle, the actions taken by the Magelang City Police Department if the motorcycle riders are using "exhaust racing" are the Traffic Ticket and Seizure. The repressive step is carried out in order to realize a national legal system based on social justice and truth that animates the law and becomes a guideline in society, where the community can not only claim its rights but the police as law enforcement officers must also implement what is stated in the regulations become a legal basis in legal action (Liangwei, 2013). Where this is in line with Remedial Justice Theory, it sets out criteria in carrying out everyday law, namely the City must have a general standard to recover the consequences of actions taken by people in relation to each other (Liu \& Sharma, 2019). Criminal sanctions are imposed, restore what has been done by the makers of crime and compensation to recover civil errors. The standard is applied without discrimination (Marusin, Marusin, \& Danilov, 2018).

\section{A. Reasons for Legal Action}

Based on an Interview with Bribka Ronny Baur Traffic Police Traffic Magelang Magelang City, Baur Police ticket Magelang City Police Station on September 13, 2017, he said:

The pollution caused by the exhaust is clearly air pollution because the exhaust emits the second exhaust emission which is noise pollution where the "racing exhaust" is identical to the loud sound and there is also a ringing ear. Therefore the police are cracking down on the existence of "racing exhausts" in order to minimize noise disturbance caused by the exhaust.

Muffler is a channel to dispose of the combustion from combustion in an internal combustion engine and has a function as a distributor of exhaust gases resulting from the combustion of fuel combustion by the engine (Metsker, Trofimov, Petrov, \& Butakov, 2019). While Racing means speeding (racing). So it can be concluded that "racing exhaust" is the exhaust drain from combustion results on a motorcycle racing engine. The use of "racing exhaust" itself on a motorcycle is believed to increase the performance of the vehicle on which the user is riding. Jam performance is increasingly high use of "racing exhaust" is felt to make the vehicle ride fierce because when the vehicle is driven on the road the sound of the muffler is very loud not smooth like a motorcycle in general.

From this understanding, we can conclude that the pollution caused by the use of "racing exhaust" is air pollution and noise pollution. Sound disturbances to some degree can be adapted physically but nerves can be disrupted. Sound hardness can have a negative impact on human health, if it continues, sound noise of 30-65 dB will disturb the ear membrane and cause anxiety, 65-90 dB will damage the vegetative layer of humans (heart, blood circulation, etc.), if it reaches $90-130 \mathrm{~dB}$ will damage the ear (Satwiko, P. 2004). 


\title{
B. Effects of Pollution Caused by Racing Exhaust
}

Based on interviews conducted by the author with Mr. Soleh Achirudin Manager of vehicle testers at the Department of Transportation on September 15, 2017. It was explained that there are impacts caused by motorcycle exhaust emissions.

\begin{abstract}
"Contaminants which are mainly found in motor vehicle exhaust gases are carbon monoxide (CO), various hydrocarbon compounds, various oxides of nitrogen (NOx) and sulfur (SOx), and dust particulates including lead (PB). Certain fuels, such as hydrocarbons and organic lead, are released into the air due to evaporation from the fuel system. Motorized vehicle traffic can also increase specific levels of dust from road surfaces, tire and brake components."
\end{abstract}

One of the substances released from the combustion of motor vehicles is carbon dioxide (CO2). Carbon dioxide if neglected, the concentration will accumulate in the atmosphere and potentially cause global warming and in the long run will result in climate change which is dangerous for human life (Mohammed, Schrock, \& Jaff, 2019).

Apart from the effects of exhaust gases, there are also effects from the sound generated. Sound disturbances to some extent can be adapted physically but nerves can be disrupted(Mohan, 2019). Sound hardness can have a negative impact on human health, if it continues, sound noise of 30-65 dB will disturb the ear membrane and cause anxiety, 65-90 dB will damage the vegetative layer of humans (heart, blood circulation, etc.), if it reaches $90-130 \mathrm{~dB}$ will damage the ear (Satwiko, 2004).

\section{CONCLUSION}

Law enforcement regarding the use of the Motorcycle "Muffler Racing" is as it should be in accordance with what is mandated by Law No.22 of 2009 concerning Road Traffic and Transportation. However, technical regulations that are listed in Ministerial Regulation No.7 of 2007 concerning Noise Threshold are not implemented because in the enforcement of the use of 'Racing Muffler' the Police element is constrained by measuring instruments which are currently only owned by the Department of Transportation. or motor vehicle operation. In the operation of the vehicle, the actions taken by the Magelang Municipal Police if the motorcycle riders are using "exhaust racing" are Ticket and Foreclosure. The reason for the action considering the pollution caused by "racing exhaust" is air pollution and noise pollution. The pollution has an impact that not only damages human health but also damages the environment. 


\section{REFERENCES}

Adnan, M., \& Gazder, U. (2019). Investigation of helmet use behavior of motorcyclists and effectiveness of enforcement campaign using the CART approach. IATSS Research, 43(3), 195-203. https://doi.org/10.1016/j.iatssr.2019.02.001

Alghuson, M., Abdelghany, K., \& Hassan, A. (2019). Toward an integrated traffic law enforcement and network management in connected vehicle environment: Conceptual model and survey study of public acceptance. Accident Analysis \& Prevention, 133(August), 105300. https://doi.org/10.1016/j.aap.2019.105300

Ali, Q., Yaseen, M. R., \& Khan, M. T. I. (2019). The causality of road traffic fatalities with its determinants in upper middle income countries: A continent-wide comparison. Transportation Research Part A: Policy and Practice, 119(November 2018), 301-312. https://doi.org/10.1016/j.tra.2018.12.002

Aney, M. S., \& Ho, C. (2019). Deadlier road accidents? Traffic safety regulations and heterogeneous motorists' behavior. Regional Science and Urban Economics, 77, 155171. https://doi.org/10.1016/j.regsciurbeco.2019.04.003

Arifin, R. (2019). How to advocate for people who have problems with the law? A Book Review Communication in Legal Advocacy, Richard Ricke \& Randall K. Stutman, South Carolina University Press. Indonesian Journal of Advocacy and Legal Services, 1(1), 157-158. https://doi.org/10.15294/ijals.vlil.33807

Arya, W. (1995). Dampak Pencemaran Lingkungan. Yogyakarta: Andi

Bracco, E. (2018). A fine collection: The political budget cycle of traffic enforcement. Economics Letters, 164, 117-120. https://doi.org/10.1016/j.econlet.2018.01.011

Castillo-Manzano, J. I., Castro-Nuño, M., López-Valpuesta, L., \& Pedregal, D. J. (2019). From legislation to compliance: The power of traffic law enforcement for the case study of Spain. Transport Policy, 75, 1-9. https://doi.org/10.1016/j.tranpol.2018.12.009

Crisanti, A. S., Earheart, J. A., Rosenbaum, N. A., Tinney, M., \& Duhigg, D. J. (2019). Beyond crisis intervention team (CIT) classroom training: Videoconference continuing education for law enforcement. International Journal of Law and Psychiatry, 62(December 2018), 104-110. https://doi.org/10.1016/j.ijlp.2018.12.003

Dur, R., \& Vollaard, B. (2019). Salience of law enforcement: A field experiment. Journal of Environmental Economics and Management, 93, 208-220. https://doi.org/10.1016/j.jeem.2018.11.011

Dzhuruk, D., \& Zedgenizov, A. (2018). Forecasting of traffic intensity on suburban routes. Transportation Research Procedia, 36(SPbOTSIC), 135-140. https://doi.org/10.1016/j.trpro.2018.12.055

Factor, R. (2018). Reducing traffic violations in minority localities: Designing a traffic enforcement program through a public participation process. Accident Analysis and Prevention, 121(July), 71-81. https://doi.org/10.1016/j.aap.2018.09.005

Friehe, T., Pham, C. L., \& Miceli, T. J. (2018). Law enforcement in a federal system: Endogenous timing of decentralized enforcement effort. International Review of Law and Economics, 56, 134-141. https://doi.org/10.1016/j.irle.2018.09.002 
Guimarães, A. G., \& da Silva, A. R. (2019). Impact of regulations to control alcohol consumption by drivers: An assessment of reduction in fatal traffic accident numbers in the Federal District, Brazil. Accident Analysis and Prevention, 127(January), 110-117. https://doi.org/10.1016/j.aap.2019.01.017

Juliana, R. \& Arifin, R. (2019). Anak dan Kejahatan (Faktor Penyebab dan Perlindungan Hukum). Jurnal Selat, 6(2), 225-234. DOI: https://doi.org/10.31629/selat.v6i2.1019

Lee, J., Park, B. J., \& Lee, C. (2018). Deterrent effects of demerit points and license sanctions on drivers' traffic law violations using a proportional hazard model. Accident Analysis and Prevention, 113(January), 279-286. https://doi.org/10.1016/j.aap.2018.01.028

Liangwei, J. (2013). Construct Humanized Off-site Enforcement System for Road Traffic Management. Procedia - Social and Behavioral Sciences, 96(Cictp), 1378-1382. https://doi.org/10.1016/j.sbspro.2013.08.156

Liu, C., \& Sharma, A. (2019). Are you going to get a ticket or a warning for speeding? An autologistic regression analysis in Burlington, VT. Transportation Research Interdisciplinary Perspectives, 1, 100001. https://doi.org/10.1016/j.trip.2019.100001

Marusin, A., Marusin, A., \& Danilov, I. (2018). A method for assessing the influence of automated traffic enforcement system parameters on traffic safety. Transportation Research Procedia, 36, 500-506. https://doi.org/10.1016/j.trpro.2018.12.136

Mathijsen, D. (2017). Young Dutch engineers are set to save the planet using carbon fiber motor racing technology. Reinforced Plastics, 61(5), 284-288. https://doi.org/10.1016/j.repl.2017.03.003

Metsker, O., Trofimov, E., Petrov, M., \& Butakov, N. (2019). Russian Court Decisions Data Analysis Using Distributed Computing and Machine Learning to Improve Lawmaking and Law Enforcement. Procedia Computer Science, 156, 264-273. https://doi.org/10.1016/j.procs.2019.08.202

Mohammed, H., Schrock, S., \& Jaff, D. (2019). The challenges impeding traffic safety improvements in the Kurdistan Region of Iraq. Transportation Research $\begin{array}{lll}\text { Interdisciplinary } \quad \text { Perspectives, } & \text { (xxxx), }\end{array}$ https://doi.org/10.1016/j.trip.2019.100029

Mohan, D. (2019). Traffic safety: Rights and obligations. Accident Analysis and Prevention, 128(April), 159-163. https://doi.org/10.1016/j.aap.2019.04.010

Moore, D. (2019). Law enforcement 9. https://doi.org/10.1016/B978-0-12-812153-5.00009-1

Muhtada, D., \& Arifin, R. (2019). Penal Policy and the Complexity of Criminal Law Enforcement: Introducing JILS 4(1) May 2019 Edition. JILS (Journal of Indonesian Legal Studies), 4(1), 1-6. https://doi.org/10.15294/jils.v4i01.30189

Redelmeier, D. A., Tibshirani, R. J., \& Evans, L. (2003). Traffic-law enforcement and risk of death from motor-vehicle crashes: Case-crossover study. Lancet, 361(9376), 2177-2182. https://doi.org/10.1016/S0140-6736(03)13770-1 
Republic of Indonesia. (2009a). Law Number 22 of 2009 concerning Traffic and Road Transportation (Undang-undang Nomor 22 Tahun 2009 tentang Lalu Lintas dan Angkutan Jalan Raya).

Republic of Indonesia (2009b). Minister of Environment Regulation No. 7 of 2009 concerning New Type Vehicle Noise Thresholds (Peraturan Mentri Lingkungan Hidup Nomor 7 Tahun 2009 Tentang Ambang Batas Kebisingan Kendaraan Tipe Baru).

Republic of Indonesia. (2002). Law Number 2 of 2002 concerning Police (Undang-undang Nomor 2 Tahun 2002 tentang Kepolisian).

Republic of Indonesia. (2012). Government Regulation Number 55 of 2012 concerning Vehicles (Peraturan Pemerintah Nomor 55 Tahun 2012 tentang Kendaraan).

Republic of Indonesia. (1982). Law No.4 of 1982 concerning the Principle of Environmental Management (Undang-undang No.4 Tahun 1982 Tentang Pokok Pengelolaan Lingkungan Hidup).

Rosenfeld, A. (2019). Are drivers ready for traffic enforcement drones? Accident Analysis and Prevention, 122 (March 2018), 199-206. https://doi.org/10.1016/j.aap.2018.10.006

Sheng, R., Zhong, S., Barnett, A. G., Weiner, B. J., Xu, J., Li, H., ... Huang, C. (2018). Effect of traffic legislation on road traffic deaths in Ningbo, China. Annals of Epidemiology, 28(8), 576-581. https://doi.org/10.1016/j.annepidem.2018.04.004

Sholehuddin, M. (2003). Sistem Sanksi dalam Hukum Pidana. Jakarta: PT Raja Grafindo Persada.

Soekamto, S. (1986). Polisi dan Lalu Lintas, (Analisa Menurut Sosiologi Hukum). Bandung: Mandar Maju.

Soekanto, S. (2002). Faktor-Faktor Yang Mempengaruhi Penegakan Hukum. Jakarta: Raja Grafindo Persada.

Soekanto, S. (2005). Pengantar Penelitian Hukum. Jakarta: UI Press.

Soemitro, R.H. (1985). Studi Hukum Dan Masyarakat. Bandung: Alumni.

Takeuchi, Y. (2019). Law and policy for space situational awareness towards Space Traffic Management - A Japanese perspective. Journal of Space Safety Engineering, 6(2), 130-137. https://doi.org/10.1016/j.jsse.2019.05.006

van Dijk, A. J., Herrington, V., Crofts, N., Breunig, R., Burris, S., Sullivan, H., ... Thomson, N. (2019). Law enforcement and public health: recognition and enhancement of joined-up solutions. The Lancet, 393(10168), 287-294. https://doi.org/10.1016/S0140-6736(18)32839-3

Watling, C. N. (2018). Drivers' perceived legitimacy of enforcement practices for sleep-related crashes: What are the associated factors? Journal of Forensic and Legal Medicine, 54(October 2017), 34-38. https://doi.org/10.1016/j.jflm.2017.12.005

Wiens, T., Lenk, K. M., Fabian, L. E. A., \& Erickson, D. J. (2018). Law enforcement practices in the first two states in U.S. to legalize recreational marijuana. International Journal of Drug Policy, 61(April), 38-43. https://doi.org/10.1016/j.drugpo.2018.08.018

Yan, F., Yan, G., Ren, M., Tian, J., \& Shi, Z. (2018). A novel control strategy for balancing traffic flow in urban traffic network based on iterative learning 
control. Physica A: Statistical Mechanics and Its Applications, 508, 519-531. https://doi.org/10.1016/j.physa.2018.05.134 